\title{
Extracellular Proteases of the Rust Fungus Uromyces viciae-fabae
}

\author{
Martina Rauscher, Kurt Mendgen, and Holger Deising ${ }^{1}$ \\ Universität Konstanz, Fakultät für Biologie, Phytopathologie, Universitätsstr. 10, D-78434 Konstanz, FRG
}

Accepted for publication October 1, 1994

\begin{abstract}
Rauschier, M., Mendgen, K., AND Deising, H. 1995. Extracellular proteases of the rust fungus Uromyces viciae-fabae. Experimental Mycology 19, 26-34. On thigmo-inductive membranes the broad bean rust fungus Uromyces viciae-fabae differentiates complex infection structures including haustorial mother cells. Using this in vitro system, formation of extracellular proteases of the obligately biotrophic fungus was studied during infection structure differentiation. Enzyme activities occur when appressoria are formed, and extracellular washing fluids of substomatal vesicles, infection hyphae, and haustorial mother cells show complex protease pattems on polyacrylamide gels containing gelatin as substrate. The majority of the rust proteases can be classified as metallo-, including $\mathrm{Ca}^{2+}$-stabilized proteases. The presence of substrate is not required for synthesis of the enzymes. The extracellular proteases, in contrast to intracellular enzymes of this fungus, specifically degrade fibrous, hydroxyproline-rich proteins. Since such proteins are important in plants for cell wall stability and play a role in defense against fungal pathogens, the extracellular proteases of $U$. viciae-fabae may be involved in localized breaching of the host cell wall. 1995 Academic Press, Inc.

INDEX DESCRIPTORS: Extracellular proteases; fungal morphogenesis; infection structure differentiation; Uromyces.
\end{abstract}

Uredosporelings of the biotrophic rust fungi differentiate a complex series of infection structures to invade the host leaf (Deising et al., 1991; Hoch and Staples, 1991). Germ tubes grow in close contact with the cuticle and, upon perception of a specific thigmotropic signal provided by the lip of the stomatal guard cell, appressoria are formed over the stomata. Subsequently, substomatal vesicles develop in the substomatal cavity and elongate to infection hyphae. After contacting a mesophyll cell, haustorial mother cells are formed which penetrate the host cell wall in a highly localized fashion to allow formation of haustoria within the living host cell. While necrotrophs and pertotrophs secrete high activities of cell wall-degrading enzymes during infection and thus cause extended tissue maceration, breaching of plant cell walls by biotrophs is locally restricted. Re-

\footnotetext{
'To whom correspondence should be addressed. Fax: +49-7531-883035.
}

cently, we have demonstrated that formation of cell wall-degrading enzymes by the rust fungus Uromyces viciae-fabae (Pers.) Schroet. is under developmental control (Heiler et al., 1993; Mendgen and Deising, 1993). This type of regulation, together with the physico-chemical properties of these enzymes is thought to result in restricted wall degradation and maintainance of cell integrity required for biotrophy (Deising $e t$ al., 1995).

With respect to cell wall penetration, depolymerases of carbohydrate polymers have been studied extensively and are thought to be of importance to the success of the invading pathogen (Cooper, 1984; Mendgen and Deising, 1993). In recent work, structural proteins are discussed side by side with carbohydrate polymers as important determinants of cell wall stability (Carpita and Gibeaut, 1993; Showalter, 1993). Fibrous glycoproteins are known to be synthesized and directed to the cell wall as a response to challenge by pathogens 
(Hammerschmidt et al., 1984; Mazau and Esquerré-Tugayé, 1986). Hammerschmidt et al. (1984) demonstrated that incorporation of proteinaceous material into the cell wall contributes to resistance of cucumber plants to Cladosporium cucumerinum. Ball et al. (1991) presented genetic evidence that extracellular protease activity may represent a pathogenicity determinant in the hemibiotrophic fungus Pyrenopeziza brassicae. Proteolytic enzymes increase the plastic extensibility of plant cell walls (Lamport, 1970). Therefore, fungal proteases capable of breaching structural plant cell wall proteins may be important factors in host-pathogen interactions.

Fungal proteases have received only limited attention, and with few exceptions no information is available about their occurrence and role in obligate biotrophs (Frič and Wolf, 1994). With respect to their potential contribution to local cell wall degradation, the kinetics of enzyme formation during infection structure differentiation of rust fungi is of interest. Using artificial membranes providing a thigmotropic signal (Staples et al., 1983), infection structure differentiation of the rust can be induced, and this system is useful to biochemically analyze enzyme formation at developmental stages of interest. Since no differences have been found between Uromyces structures formed in planta and those formed in vitro on artificial membranes (Stark-Urnau and Mendgen, 1993) data obtained from in vitro studies may help to understand disease physiology.

\section{MATERIALS AND METHODS}

\section{Fungal Material and Infection Structure Differentiation}

Uredospore production and infection structure differentiation were done as described earlier (Deising et al., 1991). The uredial culture of $U$. viciae-fabae, originating from a single-spore-line was maintained on Vicia faba cv con amore in growth chambers at a 16-h:8-h light:dark regime and $22^{\circ} \mathrm{C}$.

Approximately $170 \mathrm{mg} U$. viciae-fabae uredospores were dusted onto each polyethylene membrane $\left(1870 \mathrm{~cm}^{2}\right)$. To induce thigmo-differentiation membranes had been scratched with brass brushes. Glass plates (no thigmotropic signal) were used when germ tube proteins were to be analyzed. After inoculation membranes or glass plates were misted with distilled $\mathrm{H}_{2} \mathrm{O}$ (4 ml per membrane) and incubated in darkness at $19^{\circ} \mathrm{C}$ at $100 \%$ relative humidity.

Germ tubes were analyzed 4 or $24 \mathrm{~h}$ after inoculation of glass plates. Structures which had developed appressoria, substomatal vesicles, and infection hyphae with increasing proportions of haustorial mother cells were harvested $7,9,14,18$, and $24 \mathrm{~h}$ after inoculation of scratched polyethylene sheets. To prepare extracellular spore proteins, spores were washed with buffer.

To investigate the effect of cycloheximide on formation of rust proteases, the inhibitor was included at 0.1 and $1.0 \mu \mathrm{g} / \mathrm{ml}$ in the spraying solution applied to inoculated membranes, resulting in germination without infection structure differentiation.

\section{Protease Extraction}

To collect extracellular enzymes of germ tubes and infection structures, membranes with adhering structures were inverted and floated each for $10 \mathrm{~min}$ on 250 to $300 \mathrm{ml}$ of $50 \mathrm{~m} M$ Pipes $^{2}(1.5 \mathrm{Na})$ buffer, pH 6.5. Glass plates were placed on spacers to avoid disruption of germ tubes. Spores were washed in $50 \mathrm{mM}$ Pipes $(1.5 \mathrm{Na})$ buffer, $\mathrm{pH} 6.5(10$ $\mathrm{ml} \mathrm{g}^{-1}$ ), with or without $0.01 \%(\mathrm{v} / \mathrm{v})$ Tween 20 . The washing fluid was filtered through a polycarbonate membrane $(0.8-\mu \mathrm{m}$ pore

\footnotetext{
2 Abbreviations used: BSA, bovine serum albumine; ConA, concanavalin A; Pipes, piperazine- $N, N^{\prime}$ bis-2-ethanesulfonic acid; PMSF, phenylmethylsulfonyl fluoride; TCA, trichloroacetic acid.
} 
size) and concentrated approximately 1000 fold by ultrafiltration using an Amicon 8200 cell with YM5 filter $(62 \mathrm{~mm})$ and a miniultrafiltration cell Model 3 with a YM5 filter (25 mm) (Amicon Corp., Danvers, MA) at 3.0 bar pressure.

Intracellular enzymes were collected by homogenizing washed fungal structures in $50 \mathrm{~m} M$ Pipes (1.5 Na)-buffer, $\mathrm{pH}$ 6.5. Homogenization of washed uredospores was carried out using a mortar and a pistil. All other structures were homogenized using a Potter-Elvehjem homogenizer. Homogenization was carried out at $4^{\circ} \mathrm{C}$. After centrifugation $(30,600 \mathrm{~g}, 15 \mathrm{~min})$ the supernatants were concentrated by $\left(\mathrm{NH}_{4}\right)_{2} \mathrm{SO}_{4}$ precipitation $(\mathrm{s}=0.8)$ and centrifugation $(38,700 \mathrm{~g}$, $30 \mathrm{~min}$ ). The pellet was dissolved in $0.5 \mathrm{mM}$ Pipes (1.5 Na)-buffer, pH 6.5, and dialyzed against the same buffer overnight. All operations were carried out at $4^{\circ} \mathrm{C}$.

\section{Enzyme Assays}

Protease activity. Enzyme assays contained $5 \mathrm{mg}$ substrate (azocoll, azoalbumin, or azocasein) $\mathrm{ml}^{-1}$. Azocoll was resuspended in buffer after washing and centrifugation $\left(12,000 \mathrm{~g}, 15 \mathrm{~min}, 4^{\circ} \mathrm{C}\right)$. Buffers used were $50 \mathrm{mM} \mathrm{Na}_{2} \mathrm{HPO}_{4} / \mathrm{KH}_{2} \mathrm{PO}_{4}$ in the $\mathrm{pH}$ range from 5 to 8 to determine the $\mathrm{pH}$ optimum, and $100 \mathrm{~m} M$ Tris- $\mathrm{HCl}, \mathrm{pH} \mathrm{8.0, \text {in }}$ all other cases. Assays were run in a total volume of 160 (azocoll) or $100 \mu$ l (azoalbumin and azocasein) at $30^{\circ} \mathrm{C}$ for 22 and $17 \mathrm{~h}$, respectively. Enzyme assays containing azocoll were shaken at 100 strokes per minute and stopped by centrifugation in an Eppendorf centrifuge at $4^{\circ} \mathrm{C}$. Assays containing azoalbumine or azocaseine were stopped by adding TCA to a final concentration of $5 \%(\mathrm{w} / \mathrm{v})$, followed by incubation on ice for $\geqslant 2 \mathrm{~h}$. TCA precipitates were pelleted by centrifugation as described above, and to the supernatant an equal volume of $0.5 \mathrm{~N} \mathrm{NaOH}$ was added. The absorbance was determined at $\lambda 520 \mathrm{~nm}$ (azocoll) or $\lambda 440 \mathrm{~nm}$ (azoalbumin and azocasein). An
OD of 1.0 indicates digested protein of $1.686 \mathrm{mg} / \mathrm{ml}$ (azocoll), $0.286 \mathrm{mg} / \mathrm{ml}$ (azocasein), or $0.313 \mathrm{mg} / \mathrm{ml}$ (azoalbumin).

Malate dehydrogenase activity. To estimate the fraction of damaged infection structures, the activity of the cytoplasmic marker enzyme NADH-malate dehydrogenase in homogenates and extracellular washing fluids was measured in the presence of $0.15 \mathrm{~m} M \mathrm{NADH}$ and $2.5 \mathrm{~m} M$ oxaloacetate in $200 \mathrm{~m} M \mathrm{~K}$-phosphate buffer, $\mathrm{pH}$ 7.5. The assay was performed at room temperature, and the decrease in absorbance at $\lambda 340 \mathrm{~nm}$ was used as a measure of malate dehydrogenase activity.

\section{Electrophoretic Procedures}

Electrophoretic separation of proteases was performed in a $4 \%$ stacking/ $10 \%$ separation gel, using the buffer system described by Laemmli (1970). The separation gels $(85 \times 75 \times 1.5 \mathrm{~mm})$ contained $0.1 \%$ $(w / v)$ gelatin. Samples of equal volumes representing extracellular proteins of identical amounts of germinated uredospores containing up to $70 \mu \mathrm{g}$ extracellular protein in sample buffer ( $50 \mathrm{~m} M$ Pipes (1.5 Na) buffer, $\mathrm{pH} 6.5$, containing $2 \%(\mathrm{w} / \mathrm{v})$ SDS, $10 \%(\mathrm{v} / \mathrm{v})$ glycerol, and bromophenol blue as front marker) were electrophoresed at 10 $\mathrm{mA}$ constant current. To analyze patterns of intracellular proteases, up to $200 \mu \mathrm{g}$ intracellular protein was loaded. SDS-PAGE was carried out at $4^{\circ} \mathrm{C}$ for $4.5 \mathrm{~h}$. After separation proteins were renatured by washing the gels in $50 \mathrm{mM}$ Tris- $\mathrm{HCl}$, $\mathrm{pH} 8.0$, containing $1 \%(\mathrm{v} / \mathrm{v})$ Triton $\mathrm{X}-100$ twice for 15 min, followed by one $15-\mathrm{min}$ wash in the same buffer without Triton $\mathrm{X}-100$. The gels were then incubated in $50 \mathrm{~m} M$ Tris- $\mathrm{HCl}$, $\mathrm{pH} 8.0$, for $\geqslant 13 \mathrm{~h}$ at $30^{\circ} \mathrm{C}$ to allow degradation of the included substrate. Gels were stained in $0.1 \%(\mathrm{w} / \mathrm{v})$ amido black in $30 \%$ $(\mathrm{v} / \mathrm{v})$ methanol and $10 \%(\mathrm{v} / \mathrm{v})$ acetic acid and destained in $30 \%(\mathrm{v} / \mathrm{v})$ methanol and $10 \%(\mathrm{v} / \mathrm{v})$ acetic acid.

To investigate substrate specificity and 
electrophoretic mobility of the extracellular proteases in the absence of substrate, separation was carried out in $10 \%$ Laemmli gels without inclusion of substrate. After electrophoresis the separated proteins were renatured as described above and the separation gel was overlayed with gels containing protease substrates. Overlay gels were $10 \%$ polyacrylamide gels containing $0.1 \%$ $(\mathrm{w} / \mathrm{v}) \mathrm{BSA}$, casein, or gelatin in $62.5 \mathrm{~m} M$ Tris-HCl, pH 8.0. Prior to assembly of separation gel and overlay, the overlay was washed in $50 \mathrm{~m} M$ Tris- $\mathrm{HCl}$, pH 8.0. The overlayed gels were incubated at $30^{\circ} \mathrm{C}$ for $19 \mathrm{~h}$ and the overlays were stained as described above.

For further characterization different inhibitors specific for cystein-proteases (E64), serin-proteases (PMSF), metalloproteases, including $\mathrm{Ca}^{2+}$-dependent or $\mathrm{Ca}^{2+}$-stabilized proteases $(1,10$ phenanthroline), and aspartic-proteases (pepstatin A) were incubated with the enzymes. PMSF and E-64 which bind covalently were added to the samples at concentrations of $1 \mathrm{mM}$ and $10 \mu M$ and incubated for $25 \mathrm{~min}$ on ice prior to electrophoresis. Pepstatin A $(1 \mu M)$ and 1,10-phenanthroline $(10 \mathrm{~m} M)$ were added to the gel washes and were also present during gel incubation.

\section{Column Chromatography}

To investigate whether the extracellular rust proteases are glycosylated, affinity chromatography was performed using a ConA-Sepharose 4B column as described (Sutton, 1990).

\section{Protein Determination}

Protein concentration was determined in $50 \mathrm{mM} \mathrm{NaOH}$, according to the method by Bradford (1976). $\gamma$-Globulin served as the standard.

\section{RESULTS}

To investigate whether extracellular pro- teases are constitutive extracellular components of rust infection structures or whether formation and/or secretion occur only at certain stages of fungal morphogenesis, extracellular material was tested for protease activity using three different dye-labeled substrates. Figure 1 shows that virtually no protease activity was present in the buffer washes of spores. Very low activity was released from 4-h-old germ tubes. After $7 \mathrm{~h}$, when appressoria are differentiated on thigmo-inductive membranes, total protease activity began to increase up to $18 \mathrm{~h}$ after inoculation, i.e., when approximately $30 \%$ of the sporelings had formed infection hyphae. The activity was not much altered at $24 \mathrm{~h}$ p.i. Both increase and maximum of protease activity were much higher using the fibrous substrate azocoll compared to those measured with the globular proteins azocasein and azoalbumin.

As can be seen from substrate containing SDS gels, protease activity associated with Uromyces infection structures is due to several different protease forms (Fig. 2a). Spores showed no enzyme activity, and at

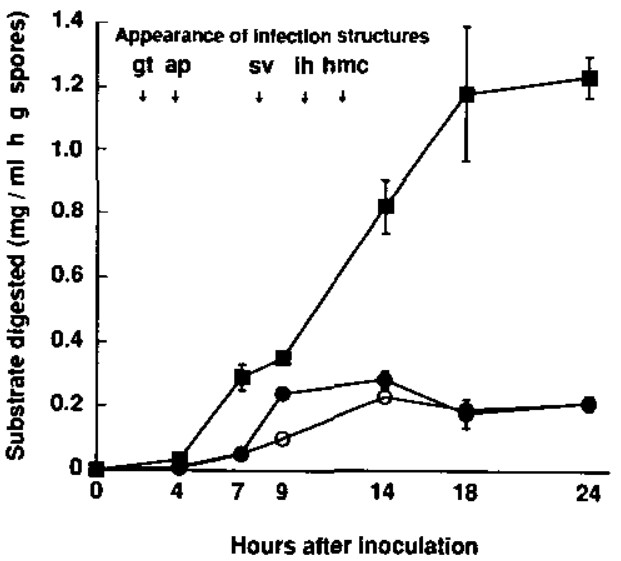

F1G. 1. Release kinetics of extracellular proteases from $U$. viciae-fabae infection structures. Extracellular enzymes were isolated by washing of structures of different morphogenetic stages as indicated, and activities were assayed with azocoll $(\boldsymbol{D})$, azoalbumin $(\mathrm{O})$, and azocasein (O) as substrates. Means and standard deviations of three independent experiments are shown. 


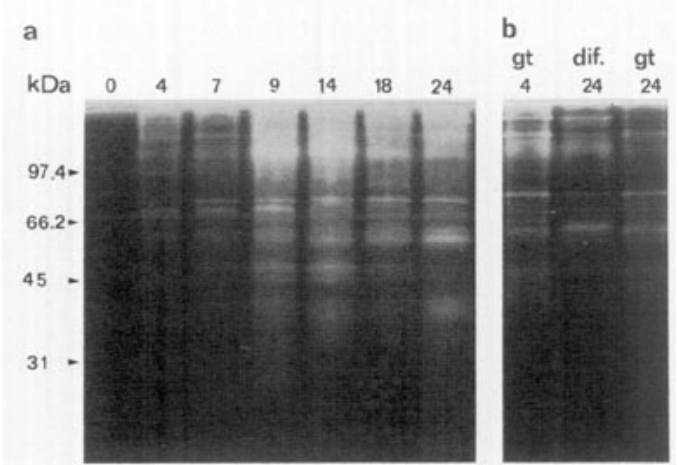

Fig. 2. Patterns of extracellular $U$. vicae-fabae proteases of different stages of infection structure differentiation. Protein, equivalent to the amount of spores used to inoculate the thigmo-inductive membranes, was loaded onto the gelatin-SDS-gel (a). After electrophoretic separation the gel was incubated and remaining substrate was stained with amido black. To analyze qualitative differences in the pattern of 4- and 24-h-old germ tubes and 24-h-old fully differentiated infection structures, equivalent protease activities were loaded (b). Electrophoreses were carried out six times using different series of washing fluids, and representative gels are shown.

the stage of 4-h-old germ tubes only faint bands were visible. From 7-h after inoculation, significant protease activity was detected on SDS-substrate gels. The extracellular washing fluids of 9-, 14-, 18-, and 24h-old infection structures exhibited a complex pattern of protease bands. Clearly, the pattern observed in the gel (Fig. 2a) is consistent with the changes in activity shown in Fig. 1. However, when spores harvested from different sets of broad bean plants were used protease patterns were not identical.

To analyze whether certain protease bands occur specifically at certain stages of rust morphogenesis and thus can be defined as differentiation-specific, the pattern of extracellular germ tube proteases was compared with those of 24-h-old differentiated infection structures and of 24-h-old germ tubes grown on glass plates (Fig. 2b). To compensate for changes in the pattern due to different levels of activities present at different stages of development, compara- ble units of protease activity were loaded. The gel shows that most proteases released from fully differentiated infection structures $(24 \mathrm{~h}$ after inoculation of inductive membranes) were also found associated with germ tubes 4 or $24 \mathrm{~h}$ after inoculation of noninductive substrata.

In addition, the protease pattern of 18-hold cycloheximide-treated infection structures and that of untreated control structures was qualitatively, but not quantitatively comparable (data not shown).

In order to find out if the preference for fibrous proteins such as collagen and its denatured form, gelatin, is specific for extracellular proteases of the broad bean rust fungus, the substrate specificities of intraand extracellular proteases were compared. Figure 3 shows that while azocollagen, a fibrous protein, is degraded at highest rates by the extracellular rust proteases, azocasein, a globular protein, represents the

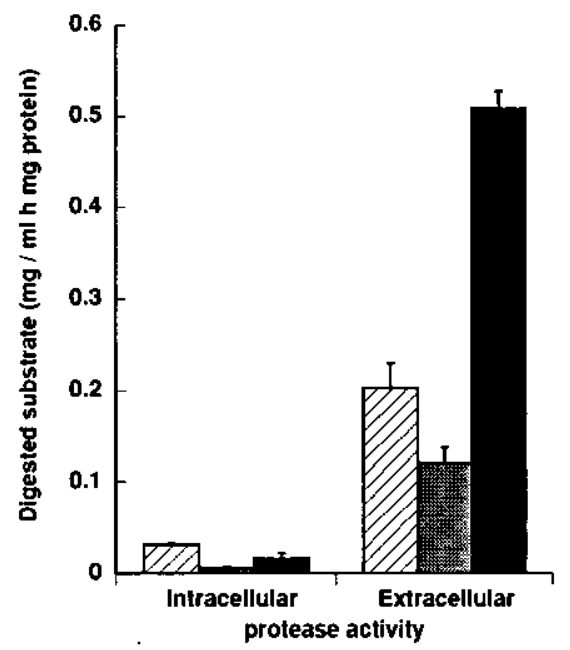

FIG. 3. Comparison of substrate specificities of extra- and intracellular proteases of $U$. viciae-fabae. Extracellular material of 24-h-old differentiated infection structures was collected by washing, and washed structures were homogenized to isolate intracellular enzymes. Activities of extra- and intracellular proteases were determined with azocoll $(\square)$, azocasein (圈), and azoalbumin ( $\square$ ) as substrates. Means and standard deviations of three independent experiments are shown. 
best substrate for intracellular proteases of this fungus. The extracellular fraction of total protease activity in 24 -h-old differentiated infection structures was $72.6 \%$ measured with azocoll. As only $0.12 \%$ of the intracellular marker enzyme malate dehydrogenase were found extracellularly, a contamination with intracellular proteases is unlikely. To demonstrate that the pattern of substrate specificities of extracellular proteases is not shifted by the presence of the azo-dye covalently linked to the substrates used in photometric assays, proteases separated by SDS-PAGE were incubated with overlay gels containing albumin, casein, or gelatin, the latter representing denatured collagen. While cleared bands indicating protease activity can be seen in gels containing gelatin, no comparable activities were observed in overlays containing globular proteins. The pattern of protease activity seen in overlay gels differed from that in substrate-containing separation gels (data not shown). This indicates that migration of proteases in substrate gels may be retarded by interaction with the copolymerized substrate. Thus, the apparent mo-

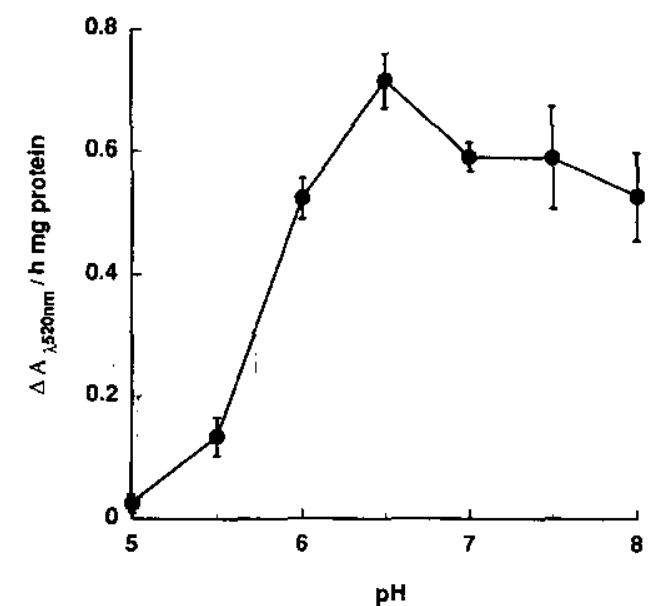

FIG. 4. pH optimum of extracellular $U$. viciae-fabae proteases. Total extracellular proteases were isolated by washing 24-h-old differentiated infection structures and assayed photometrically with azocoll as substrate. Means and standard deviations of six independent experiments are shown.

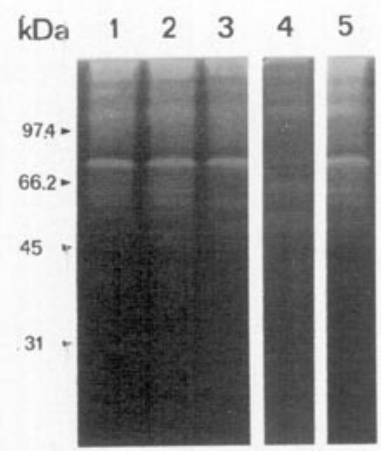

FIG. 5. Effect of different inhibitors on extracellular $U$. viciae fabae proteases. Inhibitors of cystein proteases (E-64, $10 \mu M$; lane 2$)$ and the serin proteases (PMSF, $1 \mathrm{mM}$; lane 3) were added to the samples before SDS-PAGE. Inhibitors of metallo- and $\mathrm{Ca}^{2+}$. dependent or -stabilized proteases $(1,10$-phenanthroline, $10 \mathrm{mM}$; lane 4 ) and aspartic proteases (pepstatin $A, 1 \mu M$; lane 5) were added to the gel washing and incubation buffers. Untreated proteases served as controls (lane 1). The position of marker proteins are indicated by arrowheads. The experiment was repeated three times using three different washing fluids of 18-h-old differentiated infection structures; representative gels are shown.

lecular weights determined by comparison with marker proteins could be overestimated.

For further characterization of extracellular proteases of $U$. viciae-fabae $\mathrm{pH}$ optimum, sensitivity toward different inhibitors, and binding pattern to the lectin affinity medium concanavalin A-Sepharose were tested.

Figure 4 shows that the $\mathrm{pH}$ optimum of total protease activity was 6.5 , as measured with azocoll in the photometric assay. Gel slices incubated at different $\mathrm{pH}$ indicated that additional bands at the anodic end of the gel occur at neutral and slightly basic $\mathrm{pH}$ (7 to 8) (data not shown). Since none of the other bands disappeared under slightly alkaline conditions, the gel assay was routinely run at $\mathrm{pH} \mathrm{8.0.}$

Inclusion of the cystein- and asparticprotease inhibitors E-64 and pepstatin A in the protease gel assay did not appear to alter the enzyme pattern (Fig. 5). In contrast, the presence of the serin-protease inhibitor 
PMSF reduced the intensities of two protease bands (Fig. 5). The most pronounced effect on extracellular rust proteases was caused by 1,10-phenanthroline which specifically inhibits metallo-proteases including $\mathrm{Ca}^{2+}$-dependent and $\mathrm{Ca}^{2+}$-stabilized proteases.

\section{DISCUSSION}

Fibrous proteins such as glycine-, proline-, and hydroxyproline-rich glycoproteins in dicots represent important structural components of dicotyledonous plant cell walls and are contributing to their stability (Carpita and Gibeaut, 1993; Showalter, 1993). Within a few minutes after wounding or elicitor application extensin gets insolubilized at the site of challenge (Showalter, 1993), and also de novo synthesis of extensin mRNA and protein have been demonstrated in various dicot plants in response to fungal ingress (Mazau and Esquerré-Tugayé, 1986; Showalter, 1993). In spite of the fact that these proteins contribute to the array of plant defense mechanisms (Hammerschmidt et al., 1984; Showalter, 1993), proteases of plant pathogenic fungi have received only limited attention. Evidence that fungal proteases may be important factors for establishment of the pathogen is, except for a few cases, of rather circumstantial nature. Both the formation of structural proteins as physical defense barriers and the synthesis of protease inhibitors by the plant in response to pathogen attack (Ryan, 1990) may be taken as evidences for the importance of these enzymes in pathogenesis. In addition, many plant pathogenic fungi are known to form and secrete proteases not only into medium supplemented with proteinaceous substrates but also into infected plant tissue (Hislop et al., 1982; Robertsen, 1984).

While proteases of a number of plant and insect pathogenic fungi have been investigated, only limited information is available on those of obligate biotrophs. Frič and
Wolf (1994) showed that high exo-protease activity is localized on the conidial surface of Erysiphe graminis f. sp. hordei. Endoproteases, however, were only detected after germination. Proteases of other phytopathogenic fungi such as the corn smut fungus Ustilago maydis (Hellmich and Schauz, 1988) appear to be regulated by coordinated repression/depression and substrate induction. In the rust fungus $U$. viciae-fabae the onset of major protease secretion coincides with appressorium formation. Like cellulases and pectin methylesterases, the proteases of the rust are formed independently of the presence of substrate, since uredospore-inoculated membranes were only sprayed with distilled $\mathrm{H}_{2} \mathrm{O}$. The timing of protease formation in this fungus thus appears to be genetically controlled. Differentiation-specific formation of enzymes capable of degrading major cell wall components such as cellulose and pectin have been demonstrated in $U$. viciae-fabae (Heiler et al., 1993; Mendgen and Deising, 1993). While formation of cellulase and pectin methylesterase occurs when appressoria and substomatal vesicles are differentiated, the synthesis of polygalacturonate lyase in haustorial mother cells and possibly infection hyphae is dependent on the presence of its substrate (Deising et al., 1995).

Some variability has been observed in the protease pattern of the broad bean rust infection structures; however, the factors controlling the alterations are unknown. Some protease bands showed heterogeneous binding to concanavalin A-coupled Sepharose suggesting inconsistent glycosylation (data not shown), and possibly variability in glycosylation is responsible for changes in the protease pattern observed in substrate gels.

The fact that proteases are mainly secreted by those rust infection structures, which in nature are formed after penetration through the stomatal opening of the host plant, together with their substrate specificity suggests that they may be in- 
volved in localized penetration of the plant cell wall. The broad $\mathrm{pH}$ optimum of these enzymes may indicate that they could be active in the intercellular space of infected broad bean leaves and support this assumption. Stringent proof, however, can only be provided by genetic experiments in which specific gene inactivation is performed. Since in rust fungi only transient transformation has been reported (Bhairi and Staples, 1992), such experiments can currently not be performed with rust fungi and evidence for the role of these enzymes in pathogenesis must remain circumstantial. In other systems, however, genetic approaches have been taken. Ball et al. (1991) have complemented a uv-induced mutant of the oilseed rape pathogen $P$. brassicae deficient in both protease activity and pathogenicity with genomic DNA of a fully pathogenic, protease-positive wild-type strain. A protease-positive transformant obtained was also fully pathogenic. Thus, even though specific protease gene disruption experiments and analysis of pathogenicity of the protease-deficient mutants have not been performed, the results suggest that protease activity is important during pathogenesis. In contrast, a genetically defined protease mutant of Cochliobolus heterostrophus is fully pathogenic (Walton, 1994), which is also the case for a uvinduced mutant of $C$. cucumerinum (Robertsen, 1984). Indirect evidence suggests that protease activity is not essential for pathogenicity in the system Monilinia fructigena-apple fruits as well (Hislop et al., 1982).

In conclusion, this study has shown that the rust fungus $U$. viciae-fabae forms several proteases during differentiation of infection structures. The type of enzyme formation is not defined as differentiationspecific, since a quantitatively distinct but qualitatively comparable pattern is exhibited by extracellular proteases of 4- and 24$\mathrm{h}$-old germ tubes and 24-h-old fully differentiated infection structures. The substrate specificity of the rust proteases and the timing of their synthesis suggest that they may play a role in the penetration process.

\section{ACKNOWLEDGMENT}

We thank the Deutsch Forschungsgemeinschaft for grants (Me 523/14-2) to K.M. and H.D.

\section{REFERENCES}

Ball, A. M., Ashby, A. M., Daniels, M. J., INGRAM, D. S., AND JohnSTONE, K. 1991. Evidence for the requirement of extracellular protease in the pathogenic interaction of Pyrenopeziza brassicae with oilseed rape. Physiol. Mol. Plant Pathol. 38: 147-161.

Bhairi, S. M., and Staples, R. C. 1992. Transient expression of the $\beta$-glucuronidase gene introduced into Uromyces appendiculatus uredospores by particle bombardment. Phytopathology 82: 986-989.

BradFord, M. M. 1976. A rapid and sensitive method for the quantitation of microgram quantities of protein utilizing the principle of protein dye binding. Anal. Biochem. 72: 248-254.

Carpita, N. C., and Gibeaut, D. M. 1993. Structural models of primary cell walls in flowering plants: consistency of molecular structure with the physical properties of the walls during growth. Plant J. 3: 1-30.

COOPER, R. M. 1984. The role of cell wall-degrading enzymes in infection and damage. In Plant Diseases: Infection, Damage, and Loss (R. K. S. Wood and G. J. Jellis, Eds.), pp. 13-27. Blackwell Scientific Publications, Oxford.

Deising, H., Jungblut, P. R., And Mendgen, K. 1991. Differentiation-related proteins of the broad bean rust fungus Uromyces viciae-fabae, as revealed by high resolution two-dimensional polyacrylamide gel electrophoresis. Arch. Microbiol. 155: 191-198.

Deising, H., Frittrang, A. K., Kunz, S., and Mendgen, K. 1995. Regulation of pectin methylesterase and polygalacturonate lyase activity during differentiation of infection structures in Uromyces viciae-fabae. Microbiology, in press.

FrIČ, F., AND Wolf, G. 1994. Hydrolytic enzymes of ungerminated and germinated conidia of Erysiphe graminis DC f. sp. hordei Marchal. J. Phytopathol. 140: $1-10$.

HAMmerschmidT, R., LAMPORT, D. T. A., AND Muldoon, E. P. 1984. Cell wall hydroxyproline enhancement and lignin deposition as an early event in the resistance of cucumber to Cladosporium $\mathrm{Cu}$ cumerinum. Physiol Plant Pathol. 24: 43-47. 
Heiler, S., Mendgen, K., and Deising, H. 1993. Cellulolytic enzymes of the obligately biotrophic rust fungus Uromyces viciae-fabae are regulated differentiation-specifically. Mycol. Res. 97: 77-85.

Hellmich S., AND Schauz, K. 1988. Production of extracellular alkaline and neutral proteases of Ustilago maydis. Exp. Mycol. 12: 223-232.

Hislop, E. C., Paver, J. L., and Keon, J. P. R. 1982. An acid protease produced by Monilinia fructigena in vitro and in infected apple fruits, and its possible role in pathogenesis. J. Gen. Microbiol. 128: 799 807.

Hoch, H. C., ANd Staples, R. C. 1991. Signaling for infection structure formation in fungi. In The Fungal Spore and Disease Initiation in Plants and Animals (G. T. Cole and H. C. Hoch, Eds.), pp. 25-46. Plenum, New York/London.

LAEMMLI, U. K. 1970. Cleavage of structural proteins during the assembly of the head of bacteriophage T4. Nature 227: 680-685.

LAMPORT, D. T. A. 1970. Cell wall metabolism. Annu. Rev. Plant Physiol. 21: 235-270.

Mazau, D., and Esquerré-Tugayé, M. T. 1986. Hydroxyproline-rich glycoprotein accumulation in the cell walls of plants infected by various pathogens. Physiol. Mol. Plant Pathol. 29: 147-157.

Mendgen, K., AND Deising, H. 1993. Infection structures of fungal plant pathogens-A cytological and physiological evaluation. New Phytol. 124: 193 213.

RoBertSEN, B. 1984. An alkaline extracellular protease produced by Cladosporium cucumerinum and its possible importance in the development of scab disease of cucumber seedlings. Physiol. Plant Pathol. 24: 83-92.

RYAN, C. A. 1990. Protease inhibitors in plants: Genes for improving defenses against insects and pathogens. Annu. Rev. Phytopathol. 28: 425-449.

Showalter, A. M. 1993. Structure and function of plant cell wall proteins. Plant Cell 5: 9-23.

Staples, R. C., Grambow, H. J., Hoch, H. C., and WYNN, W. K. 1983. Contact with membrane grooves induces wheat stem rust uredospore germlings to differentiate appressoria but not vesicles. Phytopathology 73: 1436-1439.

Stark-Urnau, M., and Mendgen, K. 1993. Differentiation of aecidiospore- and uredospore-derived infection structures on cowpea leaves and on artificial surfaces by Uromyces vignae. Can. J. Bot. 71: 1236-1242.

SuTton, C. 1990. Lectin affinity chromatography. In Protein Purification Methods-A Practical Approach (E. L. V. Harris and S. Angal, Eds.), pp. 268-282. IRL Press, Oxford/New York.

Walton, J. D. 1994. Deconstructing the cell wall. Plant Physiol. 104: 1113-1118. 